\title{
Burrow morphology of the land crab Gecarcinus lateralis and the ghost crab Ocypode quadrata on San Salvador Island, The Bahamas: comparisons and palaeoenvironmental implications
}

\author{
Koji SEIKE ${ }^{1 *} \&$ H. Allen CURRAN \\ ${ }^{1}$ Atmosphere and Ocean Research Institute, University of Tokyo, 5-1-5, Kashiwanoha, Kashiwa, 277-8564, Japan; \\ seike@aori.u-tokyo.ac.jp \\ ${ }^{2}$ Department of Geosciences, Smith College, Northampton, Massachusetts, 01063, USA; acurran@smith.edu \\ * Corresponding author
}

Seike, K. \& Curran, H.A. 2014. Burrow morphology of the land crab Gecarcinus lateralis and the ghost crab Ocypode quadrata on San Salvador Island, The Bahamas: comparisons and palaeoenvironmental implications [Morfologías de las madrigueras del cangrejo terrestre Gecarcinus lateralis y del cangrejo fantasma Ocypode quadrata en la isla de San Salvador (Bahamas): comparación e implicaciones paleoambientales]. Spanish Journal of Palaeontology, 29 (1), 61-70.

\begin{abstract}
Burrow morphologies of the land crab Gecarcinus lateralis and the ghost crab Ocypode quadrata were investigated on East Beach, San Salvador Island, The Bahamas, with the goals of critical comparison of their morphologies and of clarifying and advancing their palaeoenvironmental usefulness. In comparing land crab burrows to those of the ghost crab, the former are simpler but more variable in overall shape. $G$. lateralis burrows have a more compressed form in the transverse section of the burrow shaft and possess lower (more horizontal) shaft inclination than those of O. quadrata. In the late Holocene backshore and dune deposits on San Salvador, two types of fossil burrows were observed. On the basis of the morphologic differences documented herein between modern burrows of land and ghost crab species, one fossil burrow form can be interpreted as having been produced by G. lateralis and the other (trace fossil Psilonichnus upsilon) produced by $O$. quadrata. Because the modern burrows of these crabs are different not only in shape but also in their
\end{abstract}

RESUMEN

Las morfologías de las madrigueras del cangrejo rojo terrestre, Gecarcinus lateralis, y del cangrejo fantasma, Ocypode quadrata, se investigaron en la playa del Este (East Beach) de la isla de San Salvador (Bahamas) con el objetivo tanto de diferenciarlas definitivamente entre sí como de clarificar y avanzar en la comprensión de su significado paleoambiental. $\mathrm{Al}$ comparar las madrigueras de los cangrejos terrestres con las de los cangrejos fantasma, se observa que las primeras son más simples pero más variables en morfología. La sección transversal de las madrigueras de G. lateralis presenta una forma más comprimida que la observable en las madrigueras de $O$. quadrata, así como su inclinación, más horizontal en la parte inferior. En los depósitos dunares y de backshore del Holoceno tardío de San Salvador se han diferenciado dos tipos de madrigueras fósiles. A partir de las diferencias morfológicas observadas entre las madrigueras de las especies actuales de los cangrejos fantasma y terrestres podría interpretarse que uno de estos tipos de madrigueras fósiles fue 
environmental preference, the occurrence of trace fossils comparable to burrows of the land crab and ghost crab $(P$. upsilon) could be used as indicators of vegetated coastal dunes (land crab burrows) and beach backshore (near sea level; ghost crab burrows) palaeoenvironments.

Keywords: Coastal environments, Bahamas, Holocene, land \& ghost crab burrows, trace fossils, Psilonichnus upsilon. producido por G. lateralis y el otro (Psilonichnus upsilon) por $O$. quadrata. Puesto que actualmente las madrigueras de estas especies de cangrejos terrestres ( $G$. lateralis) y fantasma $(O$. quadrata), además de ser diferentes en morfología, también son propias de ambientes determinados, la existencia de icnofósiles comparables a sus madrigueras se puede usar como indicador de paleoambientes asociados a dunas costeras con vegetación (las del cangrejo terrestre) y de depósitos de backshore (cercano al nivel del mar; las del cangrejo fantasma).

Palabras clave: Ambientes costeros, Bahamas, Holoceno, madrigueras de cangrejos terrestre y fantasma, pistas fósiles, Psilonichnus upsilon.

\section{INTRODUCTION}

It is widely recognized today that trace fossils can provide significant information about the palaeoenvironments in which they formed. In order to utilize trace fossils as indicators for palaeoenvironmental reconstruction, detailed investigations of their modern counterpart traces and tracemakers are indispensable.

Quasi-terrestrial and terrestrial crabs are major bioturbators in tidal flat, beach, coastal marsh, mangrove, and vegetated dune environments. In particular, the burrow morphologies of ocypodid crabs such as the ghost crab, Ocypode and the fiddler crab Uca have been well studied (e.g., Vannini, 1980; Chakrabarti, 1981; Curran \& White, 1991; Lim \& Diong, 2003; De, 2005; Seike \& Nara, 2007, 2008; Netto \& Grangeiro, 2009; Lim et al., 2011; Gibert et al., 2013). Their fossil counterpart burrows have been recognized from the geological record and also have been considered as powerful tools for reconstruction of palaeoenvironments (e.g., Frey et al., 1984; Curran, 2007, Gibert et al., 2013).

Burrows of the land crab Gecarcinus lateralis can be abundant on vegetated coastal areas in the tropical western Atlantic-Caribbean region (Wolcott, 1988). However, the many previous studies of this crab provide scant information about the morphology of its burrows and virtually nothing is known about its bioturbation effects. In order to utilize fossilized crab burrows as palaeoenvironmental indicators in coastal lithofacies, it is important first to be able to recognize the full range of modern burrow morphologies of a given crab species in order to distinguish burrows of land crabs from those of ghost crabs because they inhabit adjacent but different environments. In this case, the ghost and land crabs inhabit near shoreline environments (uppermost foreshore, backshore, and unvegetated primary dune) and vegetated dunes (dry upland), respectively.
This study describes in detail the morphology and dimensions of burrows of the land crab Gecarcinus lateralis in the coastal dunes system of East Beach, San Salvador Island. In addition, the characteristics of these land crab burrows are compared with those of the ghost crab Ocypode, which have been well studied throughout the world (e.g., Vannini, 1980; Chakrabarti, 1981; Curran \& White, 1991; De, 2005; Seike \& Nara, 2007, 2008; Netto \& Grangeiro 2009; Lim et al., 2011). We also make comparisons with fossil and sub-fossil counterparts of the modern ghost and land crab burrows from late Holocene backshore and coastal dune deposits on San Salvador and discuss the palaeoenvironmental implications of these burrows.

\section{FIELD SETTING AND STUDY METHODS FOR THE MODERN BURROWS}

\subsection{Study Site}

Fieldwork was carried out on East Beach, on the windward Atlantic coast of San Salvador Island (Fig. 1). Burrows produced by crabs were studied in two different depositional environments in this area: coastal vegetated dunes and a wide, gently seaward sloping backshore. Sediments of the beach and dunes are all carbonate sand. Gecarcinus lateralis and its burrows (Figs 2a-c) are abundant in the vegetated dunes, while Ocypode quadrata and its burrows (Figs 2d-f) are common on the open beach. The dune field is extensive and forms a system of ridges and troughs with meter-scale topographic undulation that has prograded seaward from mid-Holocene to present (Curran et al., 2012). These dunes are seasonally dry, 
heavily vegetated, and with no standing water present. The median grain size of the vegetated dune and backshore sediments is 0.20 and $0.24 \mathrm{~mm}$, respectively.
A

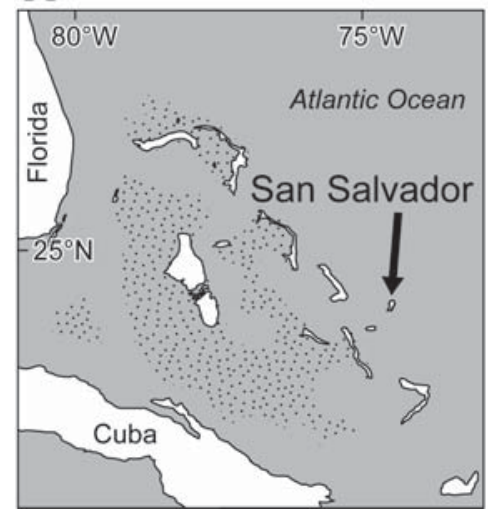

B

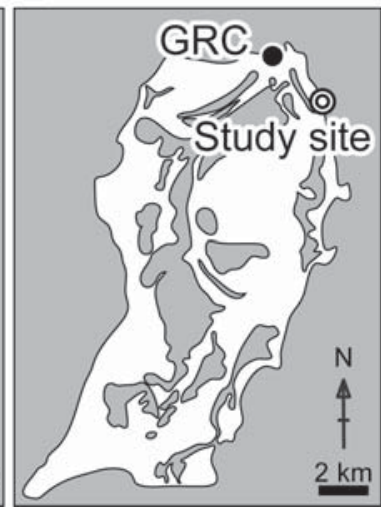

Figure 1. The Bahama Archipelago and San Salvador Island, The Bahamas. a) Location of San Salvador Island. b) Location of the East Beach study site and the Gerace Research Centre (GRC).

\subsection{Casting and measurement of modern burrows}

Casts of Gecarcinus lateralis and Ocypode quadrata burrows were obtained by pouring Plaster of Paris (gypsum plaster) down the selected burrows. After a plasterhardening period of at least 24 hours, each burrow cast was carefully excavated and returned to our laboratory at the Gerace Research Centre (GRC: Fig. 1b) for overall examination, measurements, and photography. Parameters of burrow morphology were measured for each cast as follows: diameter (width [W] and height $[\mathrm{H}]$ for axis of burrow shaft) of each cast was measured to the nearest millimeter at three points along the main shaft using a hand caliper, and then mean diameter (both for $\mathrm{W}$ and $\mathrm{H})$ was calculated for each cast. Total length (including that of main shaft and branches) was measured to the nearest centimeter using a measuring tape. Depth of each burrow, the vertical, straight-line distance from the ground surface to the end of the burrow, was measured to the nearest centimeter. Number of branches per cast was also measured. Burrow inclination near the burrow
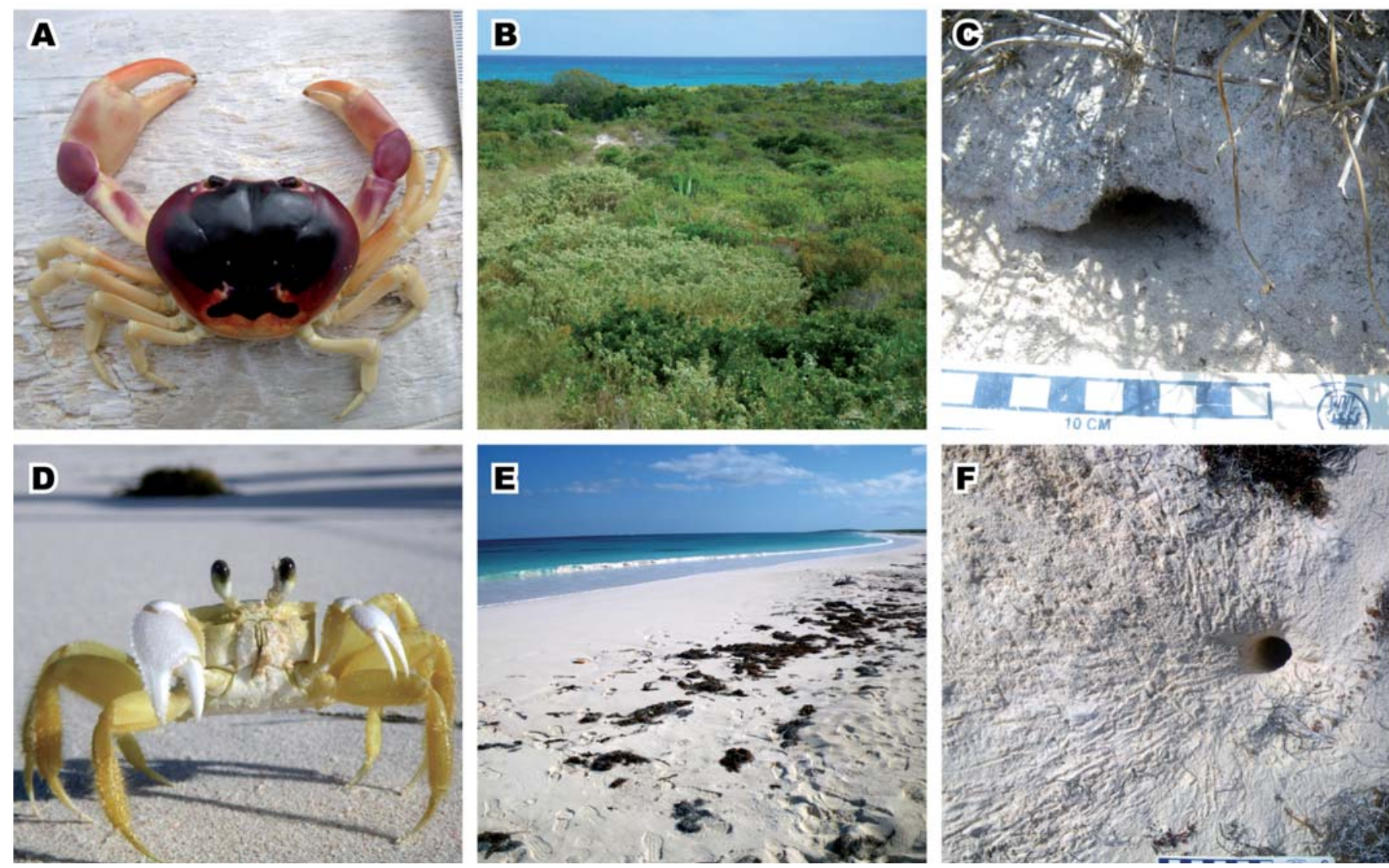

Figure 2. Land and ghost crabs and their habitats. a) The land crab Gecarcinus lateralis (Frémenville, 1835). b) View of the heavily vegetated coastal dunes behind the beach. Burrows of the land crab are abundant here. c) Aperture of a land crab burrow. d) The ghost crab Ocypode quadrata (Fabricius, 1787). e) View of the backshore of East Beach where ghost crab burrows are common. f) Aperture of a ghost crab burrow with radiating tracks; scale in $\mathrm{cm}$. 
opening was recorded using a semicircular protractor. We also recorded all ornamentation observed on the burrow cast surfaces, i.e., presence or absence of bioglyphs (sensu Ekdale \& Gibert, 2010), including scratch patterns on the burrow walls, produced by the excavation activities of the crab and pockmarks (pits created in the burrow floor by locomotion of the crab). In addition, we recorded organic material present, such as crab fecal pellets and plant leaves and fragments on the bottom surface of the burrow casts. In order to quantify further the specific characteristics of the burrows of each crab species, a statistical comparison using the Mann-Whitney U-test was made of burrow diameter shape (ratio of shaft width [W] to height [H]) and burrow inclination between the land and ghost crab burrows.

\section{ANALYSIS OF BURROW MORPHO- LOGIES OF THE LAND AND GHOST CRABS}

A total of 10 near-complete burrow casts of the land crab Gecarcinus lateralis were collected and observed. Measurement data for the land crab burrow casts are summarized in Table 1, and representative burrow casts are shown in Figure 3. To our knowledge, this is the first comprehensive ichnologic analysis of any modern gecarcinid land crab burrows. The observed diameter of the burrow (W), burrow depth, and burrow length varied from 32 to $58 \mathrm{~mm}, 8$ to $47 \mathrm{~cm}$, and 19 to $103 \mathrm{~cm}$ respectively. The transverse sections of the burrow shafts exhibited compressed shapes; average ratio between height $(\mathrm{H})$ and width (W) was 0.67. Shaft inclination to the horizontal plane ranged from $18^{\circ}$ to $47^{\circ}$ (mean: $28.9^{\circ}$ ). Overall land crab burrow morphology was variable, with almost all burrows having a meandering form without branching, except for one burrow cast with a false branch caused by a casual intersection with another burrow (cast no.: 2010EBL-2). Bioglyphs were abundant on the burrow casts, with scratch patterns present on sides and roofs of 7 burrow casts (Fig. 4a). Pockmarks were present on the floors of 8 casts (Fig. 4b). Also, organic materials consisting of fecal pellets (Figs 4b-c) of the land crab and leaves and other plant fragments (Fig. 4c) were observed on the burrow floor in 6 and 3 casts, respectively.

For the ghost crab Ocypode quadrata, a total of 36 near-complete burrow casts were obtained. Measurement data for these casts are summarized in Table 2, and representative burrow forms for $O$. quadrata are shown in Figure 5. Diameter, depth, and length of the casts varied from 12 to $48 \mathrm{~mm}, 10$ to $104 \mathrm{~cm}$, and 11 to $174 \mathrm{~cm}$, respectively. The average ratio of width to height of the shaft transverse section was 0.92 . Shaft inclination ranged from $34^{\circ}$ to $79^{\circ}$ (mean: $58^{\circ}$ ), and 23 of these burrow casts exhibited Y-branching while the remainder had a simple

Table 1. Measurement data for the land crab Gecarcinus lateralis burrow casts from the coastal dune environment of East Beach, San Salvador.

\begin{tabular}{|c|c|c|c|c|c|c|c|c|c|c|c|}
\hline \multirow[b]{2}{*}{ Cast no. } & \multicolumn{2}{|c|}{ Mean diameter $(\mathrm{mm})$} & \multirow[b]{2}{*}{$\begin{array}{c}\text { Diameter } \\
\text { ratio } \\
(\mathrm{H} / \mathrm{W})\end{array}$} & \multirow[b]{2}{*}{$\begin{array}{l}\text { Total } \\
\text { length } \\
(\mathrm{cm})\end{array}$} & \multirow[b]{2}{*}{$\begin{array}{l}\text { Depth } \\
(\mathrm{cm})\end{array}$} & \multirow[b]{2}{*}{$\begin{array}{c}\text { No. of } \\
\text { branches }\end{array}$} & \multirow[b]{2}{*}{$\begin{array}{c}\text { Shaft } \\
\text { inclination } \\
\text { (degrees) }\end{array}$} & \multicolumn{2}{|c|}{ Bioglyphs } & \multicolumn{2}{|c|}{ Organic material in burrow } \\
\hline & Height $(\mathrm{H})$ & Width (W) & & & & & & $\begin{array}{l}\text { Scratch } \\
\text { pattern }\end{array}$ & Pockmarks & Fecal pellets & $\begin{array}{l}\text { Leaves \& other } \\
\text { plant fragments }\end{array}$ \\
\hline 2010-EBL-1 & 36 & 44 & 0.82 & 91 & 47 & 0 & 35 & + & + & - & - \\
\hline 2010-EBL-2 & 17 & 32 & 0.53 & 50 & 21 & 1 & 28 & - & + & - & + \\
\hline 2010-EBL-3 & 28 & 38 & 0.74 & 90 & 37 & 0 & 47 & + & + & + & + \\
\hline 2010-EBL-4 & 30 & 38 & 0.79 & 58 & 24 & 0 & 32 & + & + & + & - \\
\hline 2010-EBL-5 & 40 & 58 & 0.69 & 103 & 37 & 0 & 32 & + & + & + & - \\
\hline 2010-EBL-6 & 25 & 39 & 0.64 & 66 & 32 & 0 & 26 & + & + & + & - \\
\hline 2010-EBL-7 & 34 & 45 & 0.76 & 95 & 24 & 0 & 28 & + & + & + & + \\
\hline 2010-EBL-8 & 27 & 39 & 0.69 & 87 & 24 & 0 & 20 & + & + & + & - \\
\hline 2010-EBL-9 & 20 & 38 & 0.53 & 20 & 8 & 0 & 23 & - & - & - & - \\
\hline 2010-EBL-10 & 13 & 38 & 0.53 & 19 & 9 & 0 & 18 & - & - & - & - \\
\hline Mean & 27 & 40.9 & 0.67 & 67.9 & 26.3 & 0.1 & 28.9 & & & & \\
\hline
\end{tabular}

$+=$ present; - $=$ not present 


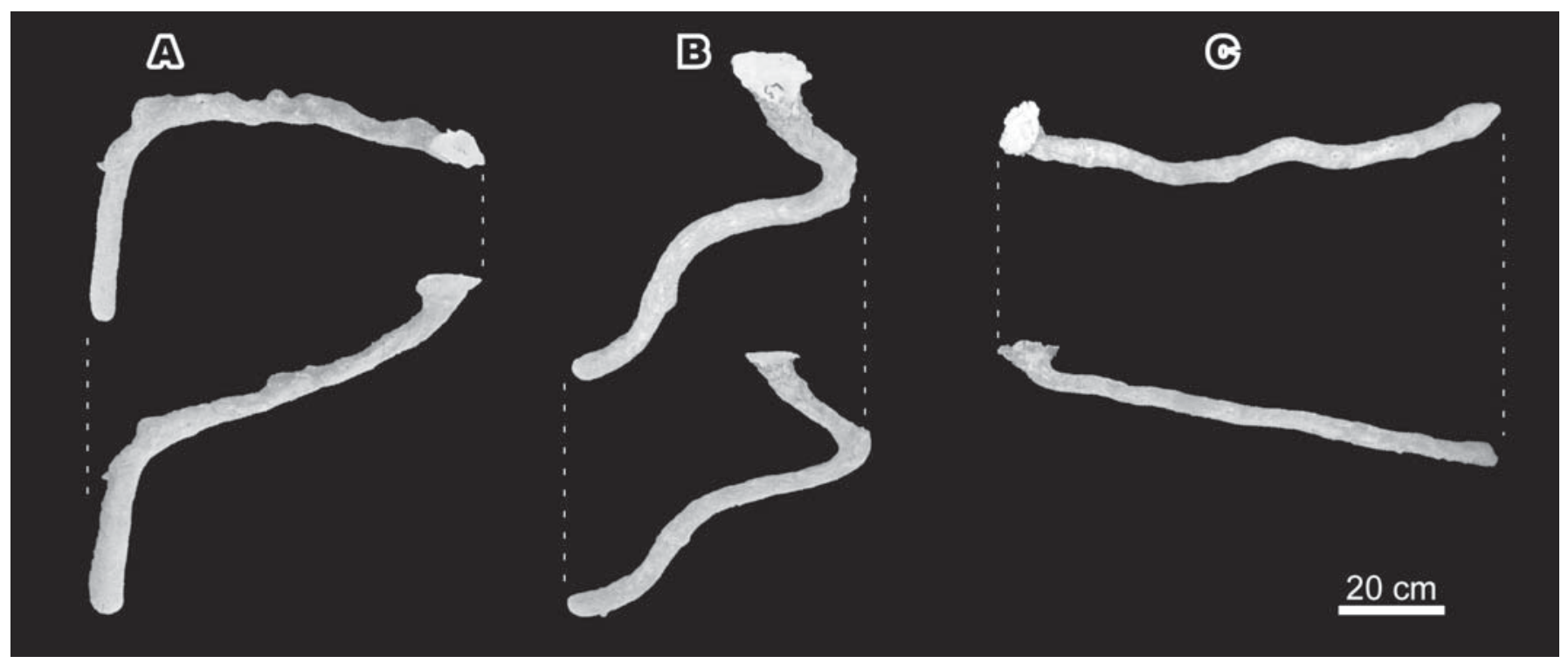

Figure 3. Plaster casts showing representative morphologies of the Gecarcinus lateralis burrows from coastal dunes of East Beach. a) Cast no. 2010-EBL-1. b) Cast no. 2010-EBL-5. c) Cast no. 2010-EBL-3. Upper and lower images represent horizontal (from above) and lateral views, respectively.

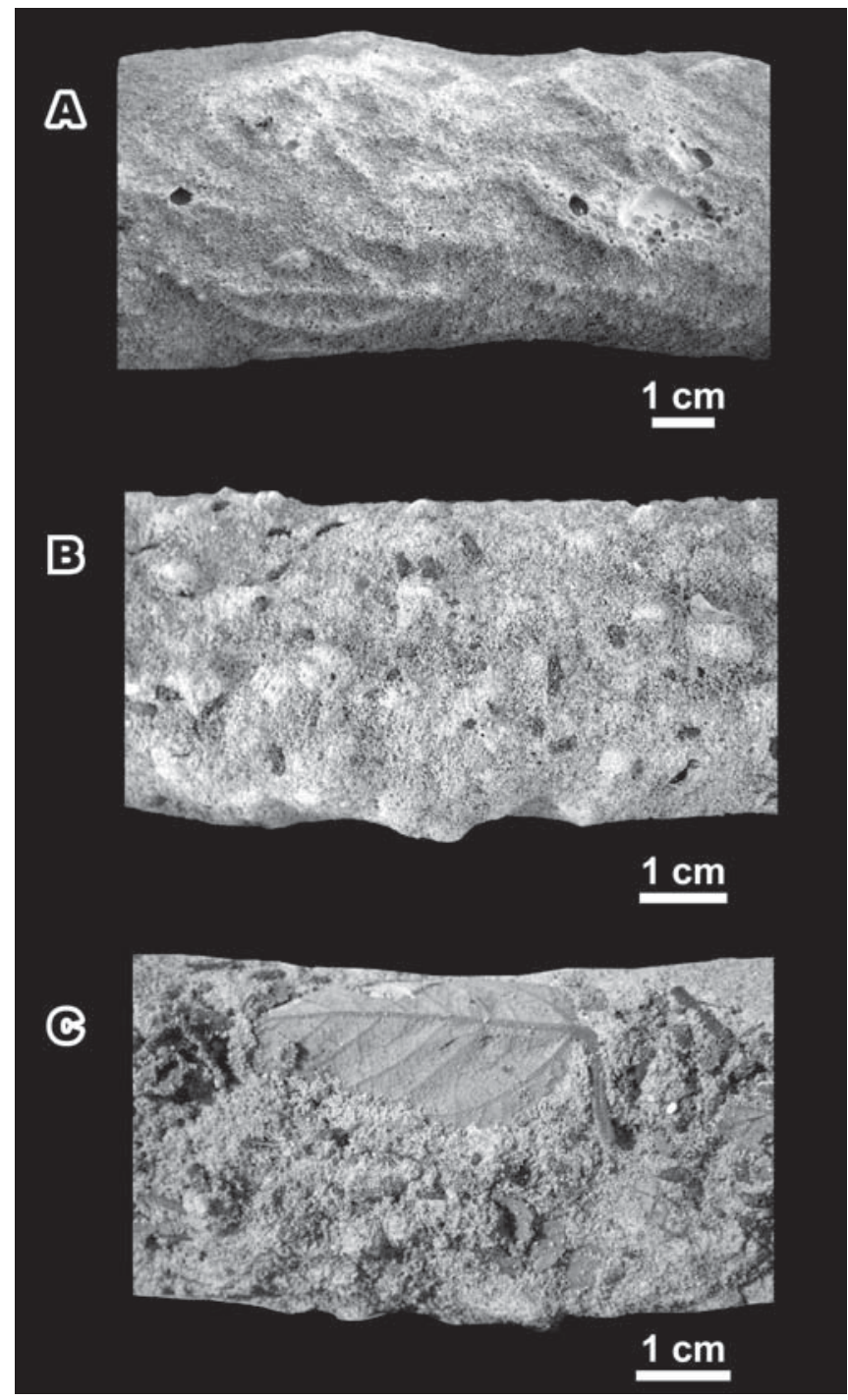

J-shaped form (Table 2). Scratch patterns and pockmarks were present in 11 and 26 of the burrow casts, respectively. In contrast to the $G$. lateralis burrows, no organic material was observed in those of $O$. quadrata.

In comparing the land crab burrows to those of the ghost crab, the former are simpler in form but more variable in overall shape. Diameter ratio $(\mathrm{H} / \mathrm{W})$ and burrow inclination for land crab burrows is significantly smaller than those parameters for ghost crab burrows $(\mathrm{P}<0.01)$, indicating that the burrows of $G$. lateralis have a more compressed form in the transverse section of the burrow shaft, and possess a much lower (more horizontal) shaft inclination than that of $O$. quadrata (Fig. 6). The percentage of burrows bearing scratch patterns is higher for burrows of G. lateralis (70\%) than for O. quadrata (31\%).

Figure 4. Representative scratch marks (bioglyphs) and organic materials occurring on Gecarcinus lateralis burrow casts as preserved on the burrow floor. a) Scratch pattern on burrow roof. b) Pockmarks and fecal pellets. c) Leaf impression and plant fragments with fecal pellets. 
Table 2. Measurement data for ghost crab Ocypode quadrata burrow casts from the backshore environment of East Beach, San Salvador.

\begin{tabular}{|c|c|c|c|c|c|c|c|c|c|c|c|}
\hline \multirow[b]{2}{*}{ Cast no. } & \multicolumn{2}{|c|}{ Mean diameter (mm) } & \multirow[b]{2}{*}{$\begin{array}{c}\text { Diameter } \\
\text { ratio } \\
(\mathrm{H} / \mathrm{W})\end{array}$} & \multirow[b]{2}{*}{$\begin{array}{l}\text { Total } \\
\text { length } \\
(\mathrm{cm})\end{array}$} & \multirow[b]{2}{*}{$\begin{array}{l}\text { Depth } \\
(\mathrm{cm})\end{array}$} & \multirow[b]{2}{*}{$\begin{array}{l}\text { No. of } \\
\text { branches }\end{array}$} & \multirow[b]{2}{*}{$\begin{array}{c}\text { Shaft } \\
\text { inclination } \\
\text { (degrees) }\end{array}$} & \multicolumn{2}{|c|}{ Bioglyphs } & \multicolumn{2}{|c|}{ Organic material in burrow } \\
\hline & Height $(\mathrm{H})$ & Width $(\mathrm{W})$ & & & & & & $\begin{array}{l}\text { Scratch } \\
\text { pattern }\end{array}$ & Pockmarks & Fecal pellets & $\begin{array}{l}\text { Leaves \& other } \\
\text { plant fragments }\end{array}$ \\
\hline 2010-EBG-1 & 31 & 32 & 0.97 & 79 & 46 & 0 & 50 & + & + & - & - \\
\hline 2010-EBG-2 & 17 & 17 & 1.00 & 70 & 49 & 1 & 72 & - & + & - & - \\
\hline 2010-EBG-3 & 28 & 30 & 0.93 & 73 & 37 & 0 & 74 & + & + & - & - \\
\hline 2010-EBG-4 & 30 & 29 & 1.03 & 63 & 29 & 0 & 79 & + & + & - & - \\
\hline 2010-EBG-5 & 34 & 31 & 1.10 & 11 & 10 & 0 & 63 & - & - & - & - \\
\hline 2010-EBG-6 & 28 & 32 & 0.88 & 98 & 33 & 1 & 43 & + & + & - & - \\
\hline 2010-EBG-7 & 28 & 35 & 0.80 & 78 & 47 & 0 & 41 & - & - & - & - \\
\hline 2010-EBG-8 & 31 & 31 & 1.00 & 83 & 52 & 1 & 64 & + & + & - & - \\
\hline 2010-EBG-9 & 31 & 31 & 1.00 & 64 & 31 & 1 & 60 & - & + & - & - \\
\hline 2010-EBG-10 & 28 & 32 & 0.88 & 94 & 54 & 1 & 36 & + & + & - & - \\
\hline 2010-EBG-11 & 40 & 47 & 0.85 & 95 & 46 & 0 & 49 & - & + & - & - \\
\hline 2010-EBG-12 & 26 & 28 & 0.93 & 38 & 15 & 0 & 46 & + & + & - & - \\
\hline 2010-EBG-13 & 19 & 23 & 0.83 & 71 & 50 & 1 & 53 & - & + & - & - \\
\hline 2010-EBG-14 & 16 & 16 & 1.00 & 55 & 42 & 1 & 67 & - & + & - & - \\
\hline 2010-EBG-15 & 30 & 32 & 0.94 & 109 & 73 & 1 & 70 & - & + & - & - \\
\hline 2010-EBG-16 & 31 & 32 & 0.97 & 63 & 45 & 0 & 70 & - & + & - & - \\
\hline 2010-EBG-17 & 14 & 15 & 0.93 & 60 & 48 & 1 & 78 & - & - & - & - \\
\hline 2010-EBG-18 & 37 & 36 & 1.03 & 15 & 13 & 0 & 75 & - & - & - & - \\
\hline 2010-EBG-19 & 30 & 40 & 0.75 & 28 & 18 & 0 & 41 & - & + & - & - \\
\hline 2010-EBG-20 & 23 & 27 & 0.85 & 117 & 33 & 1 & 34 & + & + & - & - \\
\hline 2010-EBG-21 & 31 & 35 & 0.89 & 23 & 19 & 0 & 52 & + & + & - & - \\
\hline 2011-EBG-1 & 29 & 31 & 0.94 & 112 & 66 & 1 & 55 & - & + & - & - \\
\hline 2011-EBG-2 & 20 & 21 & 0.95 & 108 & 66 & 1 & 62 & - & + & - & - \\
\hline 2011-EBG-3 & 32 & 36 & 0.89 & 108 & 75 & 1 & 39 & - & + & - & - \\
\hline 2011-EBG-5 & 30 & 33 & 0.91 & 113 & 64 & 1 & 62 & - & + & - & - \\
\hline 2011-EBG-6 & 43 & 45 & 0.96 & 174 & 104 & 1 & 63 & + & + & - & - \\
\hline 2011-EBG-7 & 34 & 39 & 0.87 & 107 & 71 & 1 & 59 & + & + & - & - \\
\hline 2011-EBG-8 & 14 & 14 & 1.00 & 57 & 42 & 2 & 65 & - & - & - & - \\
\hline 2011-EBG-9 & 21 & 21 & 1.00 & 76 & 53 & 1 & 69 & - & + & - & - \\
\hline 2011-EBG-10 & 19 & 21 & 0.90 & 85 & 61 & 1 & 72 & - & - & - & - \\
\hline 2011-EBG-11 & 12 & 12 & 1.00 & 42 & 37 & 1 & 67 & - & - & - & - \\
\hline 2011-EBG-12 & 15 & 16 & 0.94 & 51 & 47 & 0 & 63 & - & - & - & - \\
\hline 2011-EBG-13 & 33 & 34 & 0.97 & 94 & 56 & 1 & 50 & - & + & - & - \\
\hline 2011-EBG-14 & 29 & 32 & 0.91 & 113 & 91 & 1 & 59 & - & + & - & - \\
\hline 2011-EBG-15 & 40 & 46 & 0.87 & 53 & 33 & 0 & 46 & - & - & - & - \\
\hline 2011-EBG-16 & 40 & 48 & 0.83 & 110 & 72 & 1 & 41 & - & - & - & - \\
\hline Mean & 27.6 & 30 & 0.93 & 77.4 & 48 & 0.7 & 58 & & & & \\
\hline
\end{tabular}




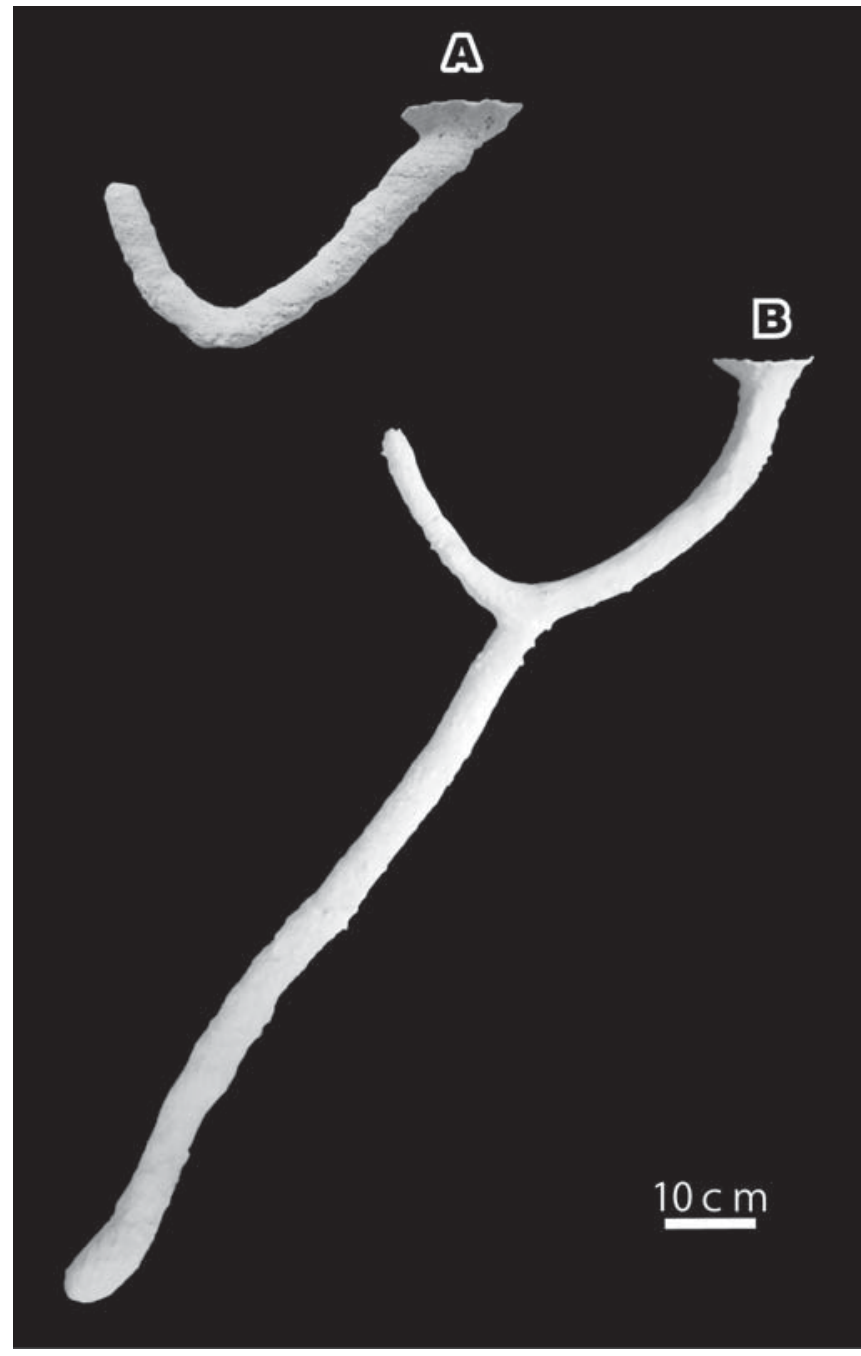

Figure 5. Representative casts of Ocypode quadrata burrows, collected from the backshore of East Beach. a) Cast no. 2011-EBG-15. b) Cast no. 2011-EBG-6.

\section{COMPARISON WITH STUDIES OF OTHER CRAB BURROWS}

Previous studies have described burrow morphologies of other tropical land crabs. For example, Shinn (1968) and Braithwaite \& Talbot (1972) described in general the burrow morphology of Cardisoma guanhumi in Florida and the Bahamas and C. carnifex in the Seychelles. Both of these crabs are common in the supratidal zone within their respective geographic areas. The burrows of Cardisoma are similar to those of Gecarcinus lateralis in their relative simplicity, but Cardisoma burrows are larger overall and have a more vertically elongated shape (Fig. 1 of plate 111 in Shinn, 1968; plate 1 in Braithwaite \& Talbot, 1972). Hence, the burrow of $G$. lateralis is differentiated from those of other land crab species by the horizontally elongated form of its burrow shaft.
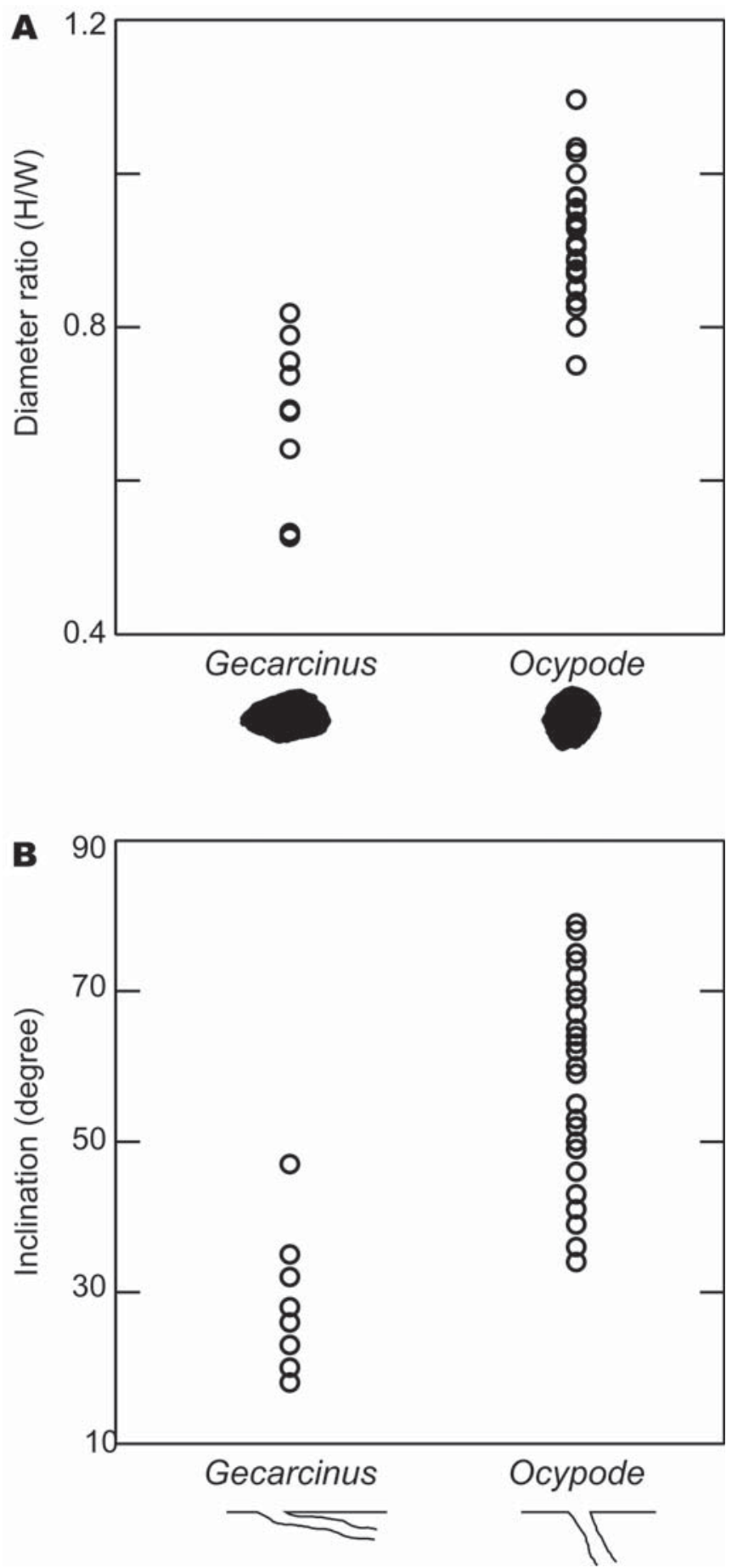

Figure 6. Comparison of burrow parameters between land and ghost crabs. a) Burrow diameter ratio. b) Inclination of burrow shaft near aperture. Note that both parameters of the land crab burrows are significantly lower than those of the ghost crab $(\mathrm{P}<0.01)$. 
Our findings on the burrow form of Ocypode quadrata are consistent with results of previous studies of this species and other Ocypode species, namely that Y- and J-shaped burrow forms are dominant (e.g., Vannini, 1980; Chakrabarti, 1981; Curran \& White, 1991; De, 2005; Seike \& Nara, 2007, 2008; Netto \& Grangeiro 2009; Lim et al., 2011). Although $O$. quadrata and Gecarcinus lateralis inhabit adjacent environmental zones (backshore and coastal dunes), their burrows are clearly distinguishable by shape (i.e., common branching versus none or only a few false branches and orientation of the shaft (i.e., vertical or horizontal). Bioglyphs, especially scratch patterns, are more common in burrows of the land crab than those of ghost crabs. Although scratch patterns are known to be produced by the excavation activity of burrowers in firmground and also in softground settings (e.g., Seike \& Nara, 2008; Ekdale \& Gibert, 2010), the higher occurrence of bioglyphs in land crab burrows over those of ghost crabs, as found in the present study, likely is caused by the greater sediment stiffness of vegetated dune sediments compared to that of backshore sediments. Further measurement of sediment stiffness over a broader range of sedimentary environments will be needed to clarify this point, because this was not part of the present study.

\section{FOSSIL COUNTERPARTS FOR THE MODERN BURROWS: PALAEOENVI- RONMENTAL IMPLICATIONS}

In the late Holocene dune deposits of the Hanna Bay Member, Rice Bay Formation on San Salvador, abundant sub-fossilized and fossilized crab burrows were observed. One form is a simple, horizontal or gently-inclined, unbranched, and compressed burrow present in the uppermost beds of coastal dune deposits (holes, as manifested in Fig. 7). The second form in somewhat older, much better lithified upper foreshore to backshore deposits are simple, inclined, Y- or J-shaped burrows that are near circular in burrow shaft cross-section and assigned to the trace fossil Psilonichnus upsilon (Fig. 8). On the basis of the documented morphologic differences between the modern burrows of land and ghost crab species, the former burrows (Fig. 7) can be interpreted with confidence as having been produced by the land crab Gecarcinus lateralis and the latter (P. upsilon) by the ghost crab Ocypode quadrata.

The occurrence of Psilonichnus upsilon has been well documented in the Holocene beach deposits on San Salvador and beyond (e.g., Frey et al., 1984; Curran \& White, 1991; Curran, 2007). In addition, our observations on the latest Holocene coastal dune deposits on San Salvador confirm that trace fossils comparable to burrows of the land crab can be preserved in the geological record. As stated earlier, the burrows of the land crab are different not only in shape but also in their environmental preference. These lines of evidence indicate that trace fossils formed by these two crabs can be utilized as indicators of palaeoenvironment - trace fossils comparable to burrows of land crabs (Gecarcinus lateralis) and ghost crabs (P. upsilon) would be indicative of coastal dunes and backshore (almost sea level) environments, respectively.

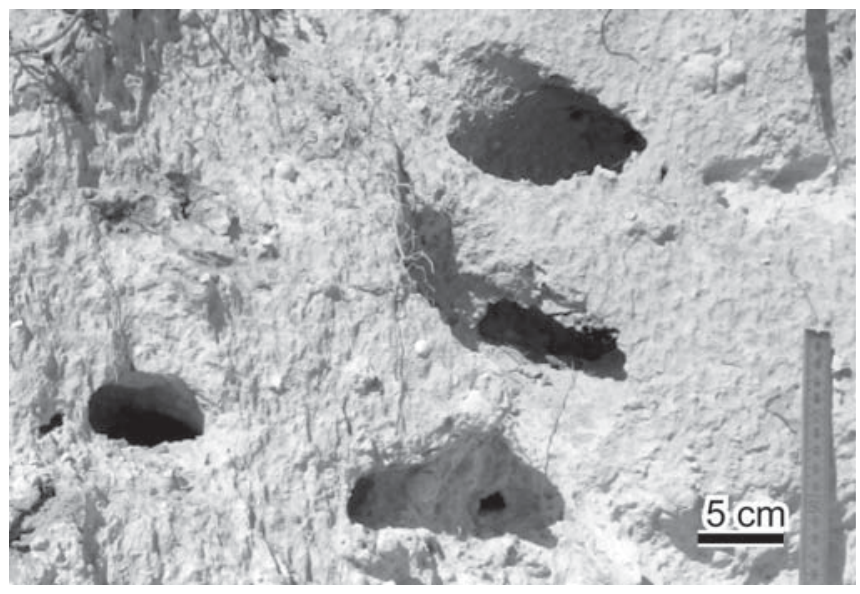

Figure 7. Example of sub-fossil land crab burrows. The uppermost dune deposits of the Hanna Bay Member, Rice Bay Formation on San Salvador are heavily bioturbated by land crabs and open holes of burrows in vertical outcrop faces are common.

Although land crabs of the genus Cardisoma make large burrows in supratidal areas, their prime habitat is different from that of Gecarcinus; the former lives only in muddy to muddy sand sediment near mangroves, swamps, and tidal creeks where its burrows can reach groundwater level, whereas the latter occupies dry upland habitats up to $1 \mathrm{~km}$ (or more) from shore and 6 to $9 \mathrm{~m}$ above high tide level (Wolcott, 1988). Furthermore, although overall burrow morphology may be similar for both genera, burrows of $G$. lateralis can be distinguished from those of Cardisoma spp. by the former's horizontally-elongated shaft, whereas the shaft of the latter is considerably larger in diameter and more circular, at least near the surface. Although we have not yet investigated Cardisoma burrows in detail, our observations indicate that fossilized land crab burrows also will prove useful for palaeoenvironmental reconstruction, i.e., the fossil counterparts of $G$. lateralis and Cardisoma spp. burrows would be accurate indicators of dry highland and wet lowland palaeoenvironments, respectively. 


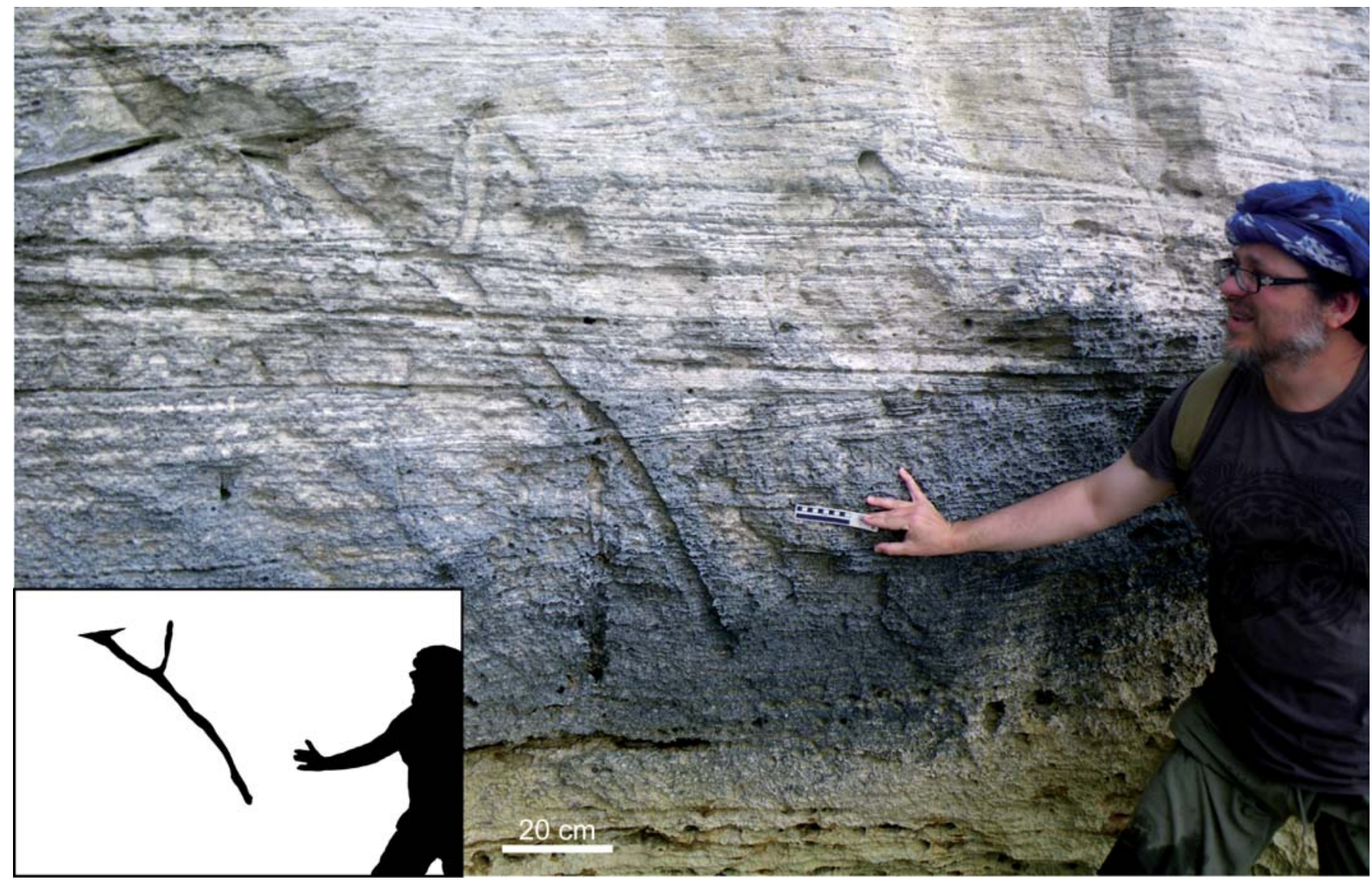

Figure 8. Dr. Jordi M. de Gibert observing the holotype specimen of the trace fossil Psilonichnus upsilon preserved in backshore deposits of the Hanna Bay Member, Rice Bay Formation on San Salvador.

\section{ACKNOWLEDGEMENTS}

This paper is dedicated to the memory of our late colleague and friend, Dr. Jordi Maria de Gibert. Jordi visited San Salvador Island twice, and he always offered lively and fruitful ichnological discussion in the field and elsewhere. He provided generous support to both of us throughout his professional career, and he is truly missed. We are grateful to the Director and staff of the Gerace Research Centre for full logistical support of our fieldwork on San Salvador.

\section{REFERENCES}

Braithwaite, C.J.R. \& Talbot, M.R. 1972. Crustacean burrows in the Seychelles, Indian Ocean. Palaeogeography, Palaeoclimatology, Palaeoecology, 11, 265-285.

Chakrabarti, A. 1981. Burrow patterns of Ocypode ceratophthalma (Pallas) and their environmental significance. Journal of Paleontology, 55, 431-441.

Curran, H.A. 2007. Ichnofacies, ichnocoenoses, and ichnofabrics of Quaternary shallow-marine to dunal tropical carbonates: a model and implications. In: Trace
Fossils: Concepts, Problems, Prospects (ed. Miller, W. III). Elsevier B.V., Amsterdam, 232-247.

Curran, H.A. \& White, B. 1991. Trace fossils of shallow subtidal to dunal ichnofacies in Bahamian Quaternary carbonates. Palaios, 6, 498-510.

Curran, H.A., Schultz-Baer, M., Durkin, K. \& Glumac, B. 2012. Recovery of carbonate sand beaches on San Salvador Island, Bahamas from damage by Hurricane Frances (2004). In: Proceedings of the 15th Symposium on the Geology of the Bahamas and Other Carbonate Regions (eds Gamble, D.W. \& Kindler, P.). Gerace Research Center, San Salvador, 1-14.

De, C. 2005. Biophysical model of intertidal beach crab burrowing: application and significance. Ichnos, 12, 11-29

Ekdale, A.A. \& Gibert, J.M. de 2010. Paleoethologic significance of bioglyphs: fingerprints of the subterraneans. Palaios, 25, 540-545.

Frey, R.W., Curran, H.A. \& Pemberton, S.G. 1984. Tracemaking activities of crabs and their significance: the ichnogenus Psilonichnus. Journal of Paleontology, 58, 333-50.

Gibert, J.M. de, Muñiz, F., Belaústegui, Z. \& Hyžný, M. 2013. Fossil and modern fiddler crabs (Uca tangeri: Ocypodidae) and their burrows from SW Spain: ichnologic and biogeographic implications. Journal of Crustacean Biology, 33, 537-551. 
Lim, S.S.L. \& Diong, C.H. 2003. Burrow-morphological characters of the fiddler crab, Uca annulipes (H. Milne Edwards, 1837) and ecological correlates in a lagoonal beach on Pulau Hantu, Singapore. Crustaceana, 76, 1055-1069.

Lim, S.S.L., Yong, A.Y.P. \& Tantichodok, P. 2011. Comparison of burrow morphology of juvenile and young adult Ocypode ceratophthalmus from Sai Kaew, Thailand. Journal of Crustacean Biology, 31, 59-65.

Netto, R.G. \& Grangeiro, M.E. 2009. Neoichnology of the seaward side of Peixe Lagoon in Mostadas, southernmost Brazil: the Psilonichnus ichnofacies revisited. Revista Brasileira de Paleontologia, 12, 211-224.

Seike, K. \& Nara, M. 2007. Occurrence of bioglyphs on Ocypode crab burrows in a modern sandy beach and its palaeoenvironmental implications. Palaeogeography, Palaeoclimatology, Palaeoecology, 252, 458-463.
Seike, K. \& Nara, M. 2008. Burrow morphologies of the ghost crab Ocypode ceratophthalma and $O$. sinensis in foreshore, backshore, and dune subenvironments of a sandy beach in Japan. Journal of the Geological Society of Japan, 114, 591-596.

Shinn, E.A. 1968. Burrowing in recent lime sediments of Florida and the Bahamas. Journal of Paleontology, 42, 879-894.

Vannini, M. 1980. Researches on the coast of Somalia. The shore and dune of Sar Uanle. 27. Burrows and digging behavior in Ocypode and other crabs (Crustacea Brachyura). Monitore Zoologico Italiano Suppl. (N.S.) $13,11-44$.

Wolcott, T.G. 1988. Ecology. In: Biology of the Land Crabs (eds Burggren, W.W. \& McMahon, B.R.). Cambridge University Press, Cambridge, 55-96. 